\title{
Process Maturity and its Determinants: An Empirical Analysis of Economic Organisations in Poland
}

Submitted 10/09/20, 1st revision 12/10/20, 2nd revision 11/11/20, accepted $22 / 11 / 20$

\author{
Agnieszka Goździewska-Nowicka ${ }^{1}$, Tomasz Janicki ${ }^{2}$
}

\begin{abstract}
:
Purpose: The aim of this article was to find factors (by using quantitative methods), which significantly influenced the increasing level of organisations process maturity, operated in Poland.

Design/Approach: Quantitative approach based on a logit model, which was created for the purpose of the study

Findings: Identifying one factor influencing the increase in the level of process maturity, which turned out to be: the desire to increase the effectiveness of the organisation understood as the possibility of additional benefits for the organisation, especially financial ones.

Practical implications: Identifying a factor that may increase the rate at which organisations achieve a higher level of process maturity.

Originality/Value: One of the first studies in the world showing the analysis of process maturity determinants in organisations, involving quantitative terms (most analyses are based on qualitative data or simple statistical analyses).
\end{abstract}

Keywords: management, process maturity, logit model.

JEL codes: M21, 049 .

Paper type: Empirical analysis.

Acknowledgement: Research financed from the WSB University research project.

\footnotetext{
${ }^{1}$ University of Science and Technology in Bydgoszcz, Faculty of Management, ORCID ID: 0000-0001-5949-3901, e-mail: agnieszka.gozdziewska@utp.edu.pl;

${ }^{2}$ Corresponding author, WSB University in Torun', Faculty of Management, ORCID ID: 0000-0002-7717-2201, e-mail: tomasz.janicki@wsb.torun.pl;
} 


\section{Introduction}

The gradual but visible resignation from traditional (classic) organisational structures and a clear tendency to follow process management methods has become a determinant of the modernisation of organisations of Central and Eastern European countries. This was undoubtedly influenced by their accession to the EU. The process maturity of business entities may be the confirmation of this tendency. Therefore, it is reasonable to assume that studying this maturity is becoming an important and almost a major current of analysis in search of the growing effectiveness of economic organisations of the aforementioned group of countries. Inevitably, research must aim to identify the determinants of these changes.

A review of the subject literature indicates a shortage of such analyses, especially in terms of econometric analyses focusing on qualitative variables. The research objective of the article is to attempt to distinguish those variables that affect the level of process maturity. The identification instrument is a logit model, which, in its assumption, implies the possibility of the occurrence of an endogenous variable that assumes a value of one or zero. The collected materials and the econometric analysis of the phenomenon of changing process maturity seem to complement the knowledge related to research on the dynamism of economic organisations and their adaptation to the requirements of the modern world.

\section{The Essence of the Process Organisation}

The term 'process organisation' is related to an organisational structure that can be a starting point for understanding the process approach to an organisation. A structure is the sum of functional and/or hierarchical dependencies between elements of one or many organisations, grouped into organisational cells and units, allowing efficient management of the functioning of an entity or a group of entities. In the classic management school, the relative stability of intra-organizational dependencies was assumed. The conditions that influenced the building of durable organisational components resulted from the need to discount the routine effect as the primary condition for maintaining a high level of system reliability (Goździewska-Nowicka et al., 2020). The man, treated as the most unreliable subject of the organisational system, obtained high implementation skills due to the high repetition of tasks performed. This translated into the experience necessary to achieve subsequent degrees of professional initiation.

Consequently, learning through years of experience has been a significant factor in the development of the science of organisation. It was the dissemination of educational systems that made a change - learning the functions, tasks, roles, behaviours, organisational processes influenced the gradual implementation of more complex relations inside and outside the organisation (Grajewski, 2010). In other words, we have witnessed the evolution of structures towards more flexible ones that allow initiating and making adaptive changes. 
Therefore, management theorists have identified some attributes of modern, flexible organisations. These include (Grajewski, 2012):

- The ability to keep up with the environmental changes and develop at an equal or faster pace than the competition.

- The ability to quickly and adaptively change the structure of intraorganizational relations, including the external boundaries of the system.

- A high level of employee validation, which is manifested in efficient and short-term decision-making processes implemented in flat organisational structures.

- Having an efficient system of identification and responding to the opinions of clients and other stakeholders of the organisation.

- Developing employees' own competences towards continuous learning of new ways of acting, and, thus, their high susceptibility to change.

- The ability to find a balance between stabilisation, necessary to achieve a high level of performance quality, and destabilisation caused by the need for frequent changes.

- Implementation of the responding system not only to the changes that were previously foreseen but also to any previously unforeseen - the ability to build a system adapting its functioning to the business environment with a high level of probability of impact of global factors.

- Making system adaptations during the operation of the system without the need to suspend its work.

The discussed flexibility often manifests itself not in classic structural solutions, but in organisational forms not focused on functions and tasks, but on processes. Therefore, process organisation becomes an alternative that increases the ability to react faster to changes in external conditions.

Thus, process organisation is a system that directs relations between the implementers of its goals to activities contained in sequential sets of activities (processes) (Grajewski, 2003). This is not a phenomenon that characterises only modern organisations - processes have been taking place in organisations which have been operating for dozens of years. Therefore, the organisational structure and process management are interrelated and co-occur. The organisational structure is a kind of organisation anatomy, processes highlight its physiology. While the aspect of organisational structures has been the subject of multifaceted analysis for decades based on research related to organisation science, the renaissance of the process approach to the analysis of the organisation's operating system was recorded at the beginning of the nineties of the last century. It is associated with the names of two American scientists T.H. Davenport and M. Hammer, and especially with the interest in the concept of reengineering - more precisely Business Process Reengineering (BPR). Proponents of the above concept unanimously point out that the key concept is the process, i.e., a set of actions most often carried out in 
sequence, which are aimed at producing a good or service with a specific level of value that would be acceptable by the customer (Skrzypek, Hofman, 2010).

\section{The Concept of the Organisation's Maturity}

Maturity, in its general meaning, is defined as the state of something or someone finally formed, reaching the final stage of development or the process of shaping. This term can be used in the biological, social and economic dimension. Phillip Crosby was one of the first to use the concept of the organisation's maturity by publishing the so-called 'Quality Management Maturity Grid' in his book entitled Quality is Free. This grid was characterised by five levels of qualitative maturity of the organisation. Its use was quite simple - the first level meant qualitatively immature organisations, whereas the fifth level meant qualitatively mature organisations. Each level was characterised by its own attributes distinguishing individual levels from each other. With the help of a special questionnaire, the organisation could easily determine its maturity level. A general scheme of the maturity model in quality management is shown below.

Figure 1. Model of the organisation's qualitative maturity

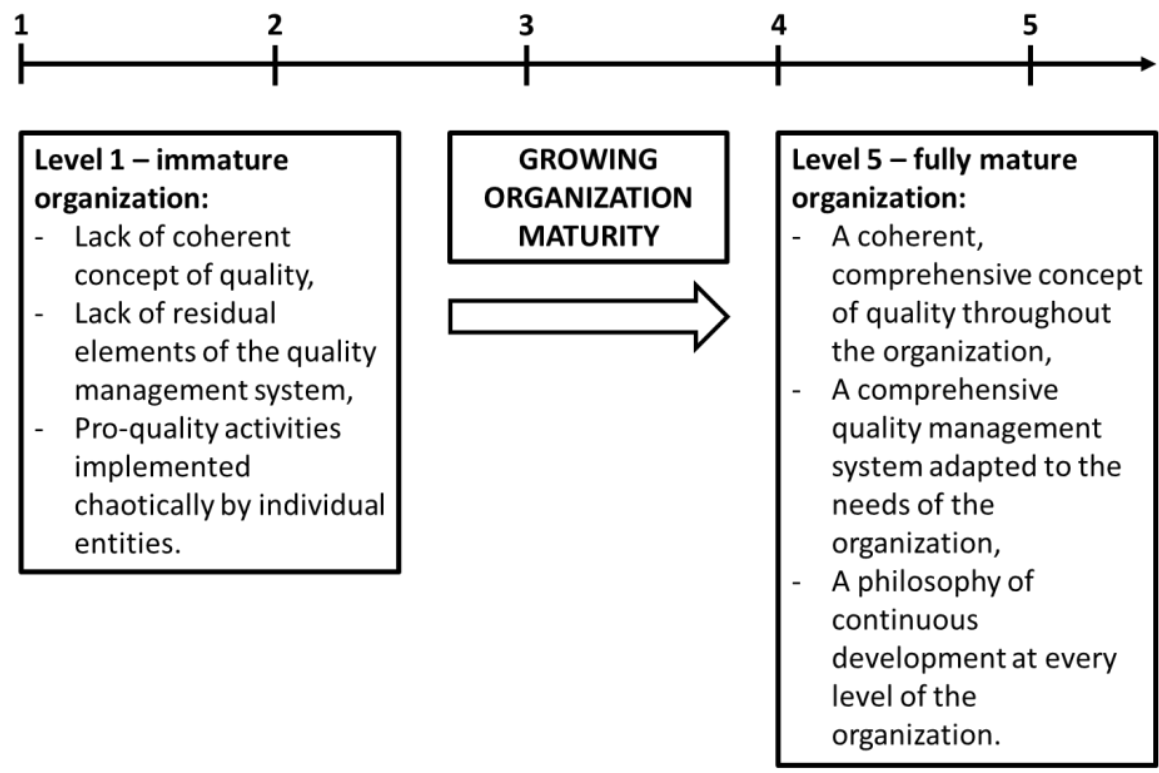

Source: Juchniewicz M., Dojrzałość projektowa organizacji, Bizarre, Warsaw 2009, p. 11.

Moreover, models of the organisation's maturity often show the path of further development of the enterprise in a given scope. In other words, they show managers the necessary actions to be taken in order to reach the next level of maturity. What is more, their universality favours popularisation and, as a consequence, the possibility 
of standing out in this respect from the competition. In the last 40 years, various models have been created in many areas of interest of the science of management, including the Brand Maturity Model, Leadership Maturity Model, and Risk Management Maturity Model.

The situation is no different within project management, which is often the starting point for the evolutionary creation of process structures. The organisation's project maturity is defined as the degree of the organisation's ability to effectively select and manage projects that aim to achieve and support the organisation's goals (Project Management Institute, 2003). Over the years, due to the constantly growing importance of project implementation by companies, many models of project maturity have been created such as, for instance, the Organizational Project Management Maturity Model, Kerzner Project Management Maturity Model, PRINCE 2 Maturity Model, PM Solutions Project Management Maturity Model. These models initiated further analytical tools - program management maturity models as well as models for project and program portfolio management. It is worth noting that the project can be defined as a unique process with a high degree of complexity. Therefore, it can be said that the issue of process maturity was the foundation, the starting point for the development of project maturity models (Juchniewicz, 2009).

The previously described Phillip Crosby's model is, more precisely, the maturity model of quality management processes. Process maturity can be treated as the level of advancement of the methods and techniques of process management used (Bitkowska, 2009), as well as the degree of awareness and knowledge about the functioning of processes in the organisation used in making decisions by management (Krukowski, 2016). The benefits of measuring process maturity include (Gibson, Dennis, and Goldenson, 2006):

- Integration of the methods and techniques used within the management system allowing identification, description, evaluation and improvement of processes;

- Continuous improvement of activities and consistent improvement of process maturity in the organisation;

- Assessment of the state of cooperation with external stakeholders (suppliers, customers, subcontractors) and translating their needs and expectations into implemented processes;

- Application of good management practices, which allows matching appropriate methods and tools of process management to the current needs reported by the organisation;

- Increasing the flexibility of operations and improving the implementation of changes in processes by developing the appropriate competencies of the organisation. 
Over the years, the above aspects have influenced the generation of many models and concepts of process maturity. According to the Association of Business Process Management Professionals, approximately one hundred and fifty different concepts of organisational maturity can currently be identified (Mielcarek, 2017). These include the Capability Maturity Model Integration (CMMI), Software Process Improvement and Capability dEtermination (SPICE) or Process and Enterprise Maturity Model (PEMM).

\section{Determinants of Process Organisation in Econometric Terms - the Logit Model}

In order to examine significant factors that may affect the development (increase) of the organisation's process maturity in 2018 and 2019, a survey was conducted using an electronic questionnaire. An invitation to participate in the study was sent to email addresses obtained from the purchased database (a database of 620,000 email addresses), which directly redirected the potential respondent to the previously prepared questionnaire. Ultimately, 240 entities took part in the study (companies, associations, cooperatives, state-owned enterprises, individuals running a business and others). Thus, the return was around $0.04 \%$. It is quite low, but according to the authors, it is sufficient to draw conclusions and generalise them.

In total, 152 micro organisations (employing from one to nine employees), 43 small organisations (employing from 10 to 49 persons), 16 medium-sized organisations (employing from 50 to 249 persons) and 29 large entities (employing over 250 persons) were surveyed. One hundred ninety-nine entities were primarily involved in providing services; the others mainly dealt with the production of goods. Most organisations, as many as 212 , were domestic entities - without the participation of foreign capital.

A logit model was used to perform an econometric analysis of the test results. Many economic phenomena are described by variables expressed in natural, monetary, etc., units, but there are also qualitative variables in economic sciences. Qualitative variables that display the behaviour of units can be represented by zero-one variables. Assuming that the decisions of individuals are rational, the economic factors underlying these decisions can be indicated using econometric models. Econometric models based on zero-one variables describe the formation of random endogenous variables that assume a value of one or zero (Kufel, 2011). The variable expressing the organisational maturity of the organisation constituted the endogenous variable in the analysis - the value zero was assigned to immature organisations, the value one was assigned to process-mature organisations. Furthermore, the explanatory variables were:

- Formal-legal requirements (e.g., related to ISO certification).

- More favourable perception of the company in the environment/greater prestige of the organisation. 
- Increasing the company's operational efficiency by reducing costs.

- Increasing the company's operational efficiency by increasing benefits (e.g., increasing revenues).

- Customer requirements.

- Counterparty requirements.

- Building internal relations.

- Building external relations.

- Competitor's activities.

- Vision of modern organisation.

The above explanatory factors were selected during meetings of Polish process management experts (who based their studies on the analysis of literature) and by conducting a pilot study. This list is not a closed set; however, due to the limitations of the research questionnaire, the most critical potential determinants affecting the phenomenon studied were selected. Respondents could select the level of impact of a given factor on a five-point scale, where five meant a strong positive impact and one a strong negative impact.

On the contrary, process maturity-immaturity was determined by selecting the most frequently appearing features of process organisation in the subject literature, for example, distinguishing between basic, auxiliary and management processes; creating process documentation in the organisation - process and relation maps; using the term value chain/added value. In total, ten of such attributes were distinguished. It was also considered that the process mature organisation was an entity with at least six characteristics out of ten - such entities were given the value one. In turn, organisations that were considered process-immature (no more than five of the features could be identified in them) were set to zero. It is evident that many other attributes could be considered as determinants of process maturity.

However, experience in conducting research indicates a correlation of two factors the more extensive the research tool is, the more often lower return of data is obtained from respondents. To estimate the logit model, the GRETL (GNU Regression Econometric and Time-series Library) software was applied. First, the function Model/Nonlinear models/Logit model/binomial... was used. It has allowed to build the model presented below in Table 1.

The result obtained contained many insignificant explanatory variables, as indicated by the $t$-Student's test. Therefore, in the second step, their sequential elimination, at the significance level of $10 \%$, was performed using the a posteriori method using the function Tests/Omitted variables test/Sequential elimination of insignificant variables... As a result, the following model 2 form was obtained as in Table 2. 
Table 1. Model 1: Logit model including all explanatory variables

Logit estimation, 1-240 observations used; Dependent variable (Y): Y

Standard errors based on the Hessian matrix

\begin{tabular}{|c|c|c|c|c|}
\hline & coefficient & standard error & $\mathbf{z}$ & marginal effect \\
\hline constant & -2.82857 & 0.866507 & -3.264 & \\
\hline X1 & 0.139721 & 0.136446 & 1.024 & 0.032566 \\
\hline X2 & -0.199927 & 0.201659 & -0.9914 & -0.0465985 \\
\hline X3 & -0.231465 & 0.202398 & -1.144 & -0.0539494 \\
\hline X4 & 0.726786 & 0.252702 & 2.876 & 0.169398 \\
\hline X5 & 0.096881 & 0.20192 & 0.4798 & 0.022581 \\
\hline X6 & -0.0610766 & 0.184631 & -0.3308 & -0.0142356 \\
\hline X7 & 0.114243 & 0.208475 & 0.548 & 0.026628 \\
\hline X8 & -0.0713369 & 0.224807 & -0.3173 & -0.0166271 \\
\hline X9 & --0.167781 & 0.178817 & -0.9383 & -0.0391060 \\
\hline X10 & 0.211071 & 0.186268 & 1.133 & 0.049196 \\
\hline
\end{tabular}

Arithmetic mean of the dependent variable 0.383333 ; The standard deviation of the dependent variable 0.487214; McFadden R-square 0.064332; Corrected $R$-square -0.004521

Log-likelihood -149.4836; Akaike Information Criterion (AIC) 320.9672

Bayesian Information Criterion (BIC) 359.2543; Hannan-Quinn Information Criterion (HQC) 336.3941

Number of 'correct prediction' cases $=157(65.4 \%)$; $\mathrm{f}$ (beta'x) to mean independent variables

Source: Own study. $=0.233$; Credibility ratio test: $C h i$-square $(10)=20.5555[0.0244]$

Table 2. Model 2: Logit model including significant explanatory variables

Logit estimation, 1-240 observations used; Dependent variable (Y): Y Standard errors based on the Hessian matrix

\begin{tabular}{|c|c|c|c|c|}
\hline & coefficient & standard error & $\mathbf{z}$ & marginal effect \\
\hline constant & -2.76266 & 0.673515 & -4.102 & \\
\hline $\mathrm{X} 4$ & 0.556808 & 0.157531 & 3.535 & 0.130304 \\
\hline
\end{tabular}

Arithmetic mean of the dependent variable 0.383333 ; The standard deviation of the dependent variable 0.487214; McFadden R-square 0.044500; Corrected $R$-square 0.031982

Log-likelihood -152.6519; Akaike Information Criterion (AIC) 309.3038

Bayesian Information Criterion (BIC) 316.2651; Hannan-Quinn Information Criterion (HQC) 312.1087

Number of 'correct prediction' cases $=151(62.9 \%)$; $($ beta'x $)$ to mean independent variables Source: Own study. $=0.234$; Credibility ratio test: $C h i$-square $(1)=14.2189$ [0.0002]

A characteristic feature of all logit models is the low level of explanation of variability (McFadden $R$-square coefficient is only 0.044500). The basic way to evaluate the logit model (forecast accuracy) is to calculate the odds ratio based on 
the odds ratio table. This table was also shown in the model estimated by the GRETL software (Table 3).

Table 3. The odds ratio table for the estimated logit model including significant explanatory variables

\begin{tabular}{|c|c|c|c|}
\hline \multicolumn{2}{|c|}{} & \multicolumn{2}{c|}{ Projected } \\
\cline { 3 - 4 } \multicolumn{2}{|c|}{} & 0 & 1 \\
\hline \multirow{2}{*}{ Empirical } & 0 & 103 & 45 \\
\cline { 3 - 4 } & 1 & 44 & 48 \\
\hline
\end{tabular}

Source: Own study.

The odds ratio $(\mathrm{OR})$ is $(103 * 48) /(45 * 44)$, i.e., 2.497 . Any result above one means that forecasting based on the model is better than random forecasting.

In the logit model, the only significant explanatory variable turned out to be increasing the effectiveness of the organisation by increasing benefits (e.g., increasing revenues). The model also informs, through the $+/$ - sign and the value of the marginal effect, that in the event of an increase in the effectiveness of the organisation by increasing the benefits, the probability of increasing the institution's process maturity will increase (by 0.130304 percentage points). In other words, according to the model created, the process maturity of organisations operating in Poland depends on the benefits achieved by these organisations, especially financial ones.

Therefore, it can be concluded that achieving higher process maturity is conditioned by the awareness of the organisation's decision-makers about the potential benefits, especially the generation of additional revenues.

\section{Conclusion}

This article was intended to show the possibility of analysing the received data in a more advanced, quantitative way. Using the logit model allowed to draw an interesting conclusion - only one parameter (factor) has an impact on the examined variable (on process maturity - on increasing its level). On the one hand, such a small number of important factors may surprise the reader, but on the other hand, economic practice indicates a simple dependency: if a solution generates additional benefits for the organisation, it is worth applying it. It should be remembered that the enterprises examined were private sector organisations, for which profit maximisation was an important element. It can be achieved by maximising revenues or minimising costs.

In the era of EU policy placing a particular emphasis on appropriate (including safe) working conditions reflecting the stability of employment contracts and in the era of a limited number of the workforce on the Polish labour market, reducing costs (especially salaries) is often a challenging activity. As a consequence, many 
companies try to maximise revenue while maintaining (not increasing) the level of costs. Furthermore, if maximisation of income will be possible through the use of more advanced tools and methods of the process management concept, then the process maturity will automatically increase, as demonstrated by the logit model.

\section{References:}

Bitkowska, A. 2009. Zarządzanie procesami biznesowymi w przedsiębiorstwie. Vizja Press \& It. Warsaw, 155-156.

Gibson, D.L., Dennis, R., Goldenson, K. 2006. Performance Results of CMMI®-Based Process Improvement. Technical Report, Carnegie Mellon University www.sei.cmu.edu/reports/06tr004.pdf.

Goździewska-Nowicka, A., Janicki, T., Popławski, W., Słupska, U. 2018. Process management as a challenge for modern organisations. Innovation management in organisations, Toruń, 39-44.

Grajewski, P. 2003. Koncepcja struktury organizacji procesowej. TNOiK, Toruń, 104-105.

Grajewski, P. 2010. Elastyczność i procesowość organizacji. Iin: Czerska, M., Szpitter, A., Koncepcje zarządzania. Podręcznik akademicki. C.H. Beck, Warsaw, 128-129.

Grajewski, P. 2012. Procesowe zarządzanie organizacją. PWE, Warsaw, 13-14.

Juchniewicz, M. 2009. Dojrzałość projektowa organizacji. Bizarre, Warsaw, 46-48.

Krukowski, K. 2016. Kulturowe uwarunkowania dojrzałości procesowej urzędów miast. Wydawnictwo Naukowe Uniwersytetu Mikołaja Kopernika. Toruń, 146-147.

Kufel, T. 2011. Ekonometria. Rozwiązywanie problemów z wykorzystaniem programu GRETL. PWN, Warsaw, 142-143.

Mielcarek, P. 2017. Model dojrzałości procesowej organizacji. Management Forum, vol. 5, no. $4,8-12$.

Organisational Project Management Maturity Model. 2003. Knowledge Foundation. Project Management Institute Inc., 5-7.

Skrzypek, E., Hofman, M. 2010. Zarządzanie procesami w przedsiębiorstwie. Wolters Kluwer, Warsaw, 12-14.

Spanyi, A, 2004. Beyond Process Maturity to Process Competence. BPTrends, 10-12. 